\title{
Cultural and morphological variability of Fusarium oxysporum f.sp. ricini isolates from castor growing areas of Gujarat
}

\section{Mahendra Sangava}

Department of Plant Pathology, S.D. Agricultural University, Sardarkrushinagar- 385506 (Gujarat), India

\section{A.G. Desai}

Department of Plant Pathology, S.D. Agricultural University, Sardarkrushinagar- 385506 (Gujarat), India

\section{G.P. Gangwar*}

Castor and Mustard Research Station, S.D. Agricultural University, Sardarkrushinagar385506 (Gujarat), India

\section{P.V. Vekariya}

Department of Plant Pathology, S.D. Agricultural University, Sardarkrushinagar- 385506 (Gujarat), India

${ }^{*}$ Corresponding author. E-mail: gokilpatho@gmail.com

\begin{abstract}
Cultural and morphological variability in five isolates of Fusarium oxysporum f.sp. ricini collected from different castor growing areas of Gujarat was studied. Varied cultural characteristics, mycelial colour, substratum pigmentation, growth pattern, dry mycelial weight, sporulation and size of micro and macro conidia of all isolates was observed which were further influenced by all five culture media viz., Rose bengal medium, Potato dextrose medium, Richard's medium, Asthana and Hawker's medium and Glucose asparagine medium. There was a significant variation among all five isolates of $F$. oxysporum f.sp. ricini in respect of cultural characteristics, mycelial colour, substratum pigmentation, mycelial growth, dry mycelial weight, sporulation, size of microconidia and macroconidia. Each isolate exhibited cultural and morphological variations under influence of different culture media. The findings of present study will be useful for developing Fusarium wilt resistant castor hybrids/varieties.
\end{abstract}

Keywords: Cultural variability, Culture media, Fusarium oxysporum f.sp. ricini, Morphological variability, Sporulation, Wilt of castor

\section{INTRODUCTION}

Castor (Ricinus communis L.) is one of the most important non-edible oilseed crop of arid and semi -arid regions which belongs to genus Ricinus of Euphorbiaceae family. India is the largest castor producer in the world. The crop is affected by several biotic and abiotic stresses among which wilt disease caused by $F$. oxysporum f.sp. ricini is most important. Depending upon the crop growth stage, the seed yield loss may be extended from 39 to $77 \%$ (Raoof and NageshwarRao, 1999). The disease incidence up to $80 \%$ was recorded by Moshkin (1986) in Russia. Yield loss was observed in all cultivated castor hybrids in Gujarat (Dange et al., 1997) and as high as $85 \%$ wilt incidence was recorded under North Gujarat condition (Dange, 2003). The reduction from 10 to 40 $\%$ in yield, $8-14 \%$ in seed weight and $1-2 \%$ in oil content was reported by Lakshminarayana and Raoof (2006). During the survey on disease sce-

\section{Article Info}

DOI:10.31018/jans.v10i4.1930 Received: October 18, 2018 Revised: November 21, 2018 Accepted: November 28, 2018

\section{How to Cite}

Sangava, M. et al. (2018). Cultural and morphological variability of Fusarium oxysporum f.sp. ricini isolates from castor growing areas of Gujarat. Journal of Applied and Natural Science, 10(4): 1291-1296 
for wilt resistance. Hence, it is essential to study the variability in the wilt pathogen. Keeping this facts in mind, the present study was carried out to test cultural and morphological variability in different isolates of Fusarium oxysporum f.sp. ricini.

\section{MATERIALS AND METHODS}

The study was conducted at Castor and Mustard Research Station, S.D. Agricultural University, Sardarkrushinagar (Gujarat) during 2015-16. To study the variability among five isolates of $F$. oxysporum f.sp. ricini, different five media were tried in solid and liquid form. Growth and sporulation of five $F$. oxysporum f.sp. ricini isolates collected from different castor growing areas of Gujarat (Table 1) were studied on five media viz., Rose Bengal (RB) medium, Potato dextrose (PD) medium, Richard's medium, Asthana and Hawker's (AH) medium and Glucose asparagine (GA) medium.

The media were prepared separately according to their composition using distilled water (Sinclair and Dhingra, 1995). For study on solid media, agar @ 2.0 per cent was added in each of the medium. Both liquid and solid media were sterilised through autoclaving. The $\mathrm{pH}$ of all the media was adjusted to 6.0 by using $0.1 \mathrm{~N}$ hydrochloric acid $(\mathrm{HCl})$ or $0.1 \mathrm{~N}$ sodium hydroxide $(\mathrm{NaOH})$ solutions. Each solid media $(20 \mathrm{ml})$ were poured separately in Petri dishes under aseptic conditions. Similarly, $20 \mathrm{ml}$ of each liquid media were poured separately in $100 \mathrm{ml}$ conical flasks and then flasks containing medium were sterilised by autoclaving. All flasks or Petri dishes containing sterilized medium were inoculated with $5 \mathrm{~mm}$ disc cut from periphery of the actively growing colony of $F$. oxysporum f. sp. ricini isolates. These flasks and Petri dishes were labelled and incubated at $27 \pm 2{ }^{\circ} \mathrm{C}$ temperature. On solid media, data on colony diameter $(\mathrm{mm})$, colony characters and pigmentation were also recorded. In liquid media study, after 15 days of incubation mycelial mat was harvested and data on dry mycelial mat, sporulation, size of micro-conidia and macroconidia were recorded.

\section{RESULTS AND DISCUSSION}

The colony characteristics viz., mycelia colour, growth pattern and pigmentation of different isolates of $F$. oxysporum $\mathrm{f}$. sp. ricini exhibited on the five media were recorded and are presented in Table 2.

Varied colony characteristics of each isolate exhibited varied colony characteristics on different media. Based on mycelia colour, the isolate For 2 produced white colour and For 1 produced pale white colour in all the five media. The isolate For 4 produced pale white colour on Potato dextrose agar (PDA), Glucose asparagine agar (GAA) and Richard's agar (RA), but produced white colour on Asthana and Hawker's agar (AHA) and Rose Ben- gal agar (RBA) media. The isolates For 3 produced pale white colour on AHA, GAA and RA, but produced white colour on PDA and RBA. The isolates For 5 produced cottony white colour on PDA, RA, GAA and RBA, but produced pale white colour on AHA. Similarly, variation in substrate pigmentation by all five isolate was observed and the isolates For 1, For 2 and For 3 exhibited pale white pigmentation, while For 4 exhibited violate and For 5 exhibited white pigmentation on PDA. All the isolates exhibited pale white and pinkish pigmentation on AHA and RBA, respectively. The isolates For 1, For 2, For 3 and For 4 exhibited pale white pigmentation, but For 5 exhibited light violet pigmentation on GAA. The isolates For 1, For 3 and For 4 exhibited pale white pigmentation, but For 2 exhibited white and For 5 exhibited pale yellowish white pigmentation on RA medium. Based on growth pattern on PDA, the isolates For 1, For 2 and For 3 exhibited flat growth with regular margin, while For 4 exhibited partial flat growth with partial regular margin and For 5 exhibited fluffy cottony growth with regular margin. On AHA medium, the isolates For 1 and For 4 exhibited flat growth with regular margin, while isolate For 3 exhibited flat growth with thread like spreading at periphery and partial regular margin, For 2 exhibited slight fluffy with irregular margin and For 5 exhibited fluffy growth with regular margin. On RBA medium, all the isolates observed fluffy growth with regular margin (For 4 and For 5), partial regular margin (For 2 and For 3 ) and irregular margin (For 1). The isolates For 2 and For 3 exhibited flat growth with regular margin, while For 4 exhibited flat growth with partial regular margin and For 1 exhibited flat growth with irregular margin, but For 5 exhibited fluffy cottony growth with partial regular margin on GAA medium. The isolate For 1 and For 3 exhibited flat growth with thread like spreading at periphery with irregular margin, while For 2 and For 4 exhibited flat growth with partial regular margin and For 5 exhibited fluffy aerial cottony growth with irregular margin on RA medium. Significant variation in colony growth was noticed among five isolates of $F$. oxysporum $\mathrm{f}$. sp. ricini as well as on different media (Table 3 ).

Among the media, significantly higher mean growth $(70.60 \mathrm{~mm})$ was observed on PDA followed by RA $(66.76 \mathrm{~mm})$, AHA $(60.50 \mathrm{~mm})$ and GAA (57.33 mm). However, Minimum mean growth $(19.00 \mathrm{~mm})$ was observed on RBA. Maxi-

Table 1. List of isolates of $F$. oxysporum f.sp. ricini collected from different castor growing areas of Gujarat.

\begin{tabular}{llll}
\hline \multirow{2}{*}{ Isolates } & Locations & & \\
\cline { 2 - 4 } & Village & Taluka & District \\
\hline For 1 & Bhakhar & Dantiwada & Banaskantha \\
For 2 & Bhachau & Bhachau & Kachchh \\
For 3 & Hadiol & Himmatnagar & Sabarkantha \\
For 4 & Vinchhol & Mahemdabad & Kheda \\
For 5 & Nana Anejiya & Nakhatrana & Kachchh \\
\hline
\end{tabular}


Table 2. Cultural characteristics of five isolates of $F$. oxysporum f.sp. ricini on different media after eight days of incubation at $27 \pm 2{ }^{\circ} \mathrm{C}$.

\begin{tabular}{|c|c|c|c|c|}
\hline Media & Isolates & Cultural characteristics & $\begin{array}{l}\text { Mycelial col- } \\
\text { our }\end{array}$ & $\begin{array}{l}\text { Substratum } \\
\text { pigmentation }\end{array}$ \\
\hline \multirow{6}{*}{$\begin{array}{l}\text { Potato dex- } \\
\text { trose } \\
\text { Agar (PDA) }\end{array}$} & For-1 & Flat growth with regular margin & Pale white & Pale white \\
\hline & For-2 & Flat aerial growth with regular margin & White & Pale white \\
\hline & For-3 & Flat growth with regular margin & White & Pale white \\
\hline & For-4 & Partial flat growth with partial regular margin & Pale white & Violet \\
\hline & For-5 & Fluffy cotto & Cottony white & White \\
\hline & For-1 & Flat growth with partial $r$ & Pale white & Pale white \\
\hline \multirow{5}{*}{$\begin{array}{l}\text { Asthana and } \\
\text { Hawker's } \\
\text { agar (AHA) }\end{array}$} & For-2 & Slight fluffy growth with irregular margin & White & Pale white \\
\hline & For-3 & $\begin{array}{l}\text { Flat growth with thread like spreading at periph- } \\
\text { ery and partial regular margin }\end{array}$ & Pale white & Pale white \\
\hline & For-4 & Flat growth with regular margin & White & Pale white \\
\hline & For-5 & rgin & Pale white & Pale white \\
\hline & For-1 & lar margin & Pale white & Pink \\
\hline \multirow{5}{*}{$\begin{array}{l}\text { Rose } \\
\text { gal } \\
\text { (RBA) }\end{array}$} & For-2 & Fluffy growth with partial regular margin & White & Pink \\
\hline & For-3 & ular margin & White & Pink \\
\hline & For-4 & Fluffy & White & Pink \\
\hline & For-5 & Fluffy cottony growth with regular margin & Cottony white & Pink \\
\hline & For-1 & Flat growth with irregular margin & Pale white & Pale white \\
\hline \multirow{5}{*}{$\begin{array}{l}\text { Glucose } \\
\text { asparagine } \\
\text { agar (GAA) }\end{array}$} & For-2 & Flat growth with regular margin & White & Pale white \\
\hline & $F_{c}$ & $\begin{array}{l}\text { Flat growth with thread like spreading at periph- } \\
\text { ery and regular margin }\end{array}$ & Pale white & Pale white \\
\hline & $\begin{array}{l}\text { For-4 } \\
\text { For-5 }\end{array}$ & $\begin{array}{l}\text { Flat growth with partial regular margin } \\
\text { Fluffy cottony growth with regular margin }\end{array}$ & $\begin{array}{l}\text { Pale white } \\
\text { Cottony white }\end{array}$ & $\begin{array}{l}\text { Pale white } \\
\text { Violet }\end{array}$ \\
\hline & For-1 & $\begin{array}{l}\text { Flat growth with thread like spreading at periph- } \\
\text { ery and irregular margin }\end{array}$ & Pale white & Pale white \\
\hline & For-2 & Flat growth with partial regular margin & White & White \\
\hline \multirow[t]{3}{*}{$\begin{array}{l}\text { Richard's } \\
\text { agar (RA) }\end{array}$} & For-3 & $\begin{array}{l}\text { Flat growth with thread like spreading at periph- } \\
\text { ery and irregular margin }\end{array}$ & Pale white & Pale white \\
\hline & For-4 & Flat growth with partial regular margin & Pale white & \multirow{2}{*}{$\begin{array}{l}\text { Pale white } \\
\text { Pale yellowish } \\
\text { white }\end{array}$} \\
\hline & For-5 & Fluffy aerial growth with irregular margin & Cottony white & \\
\hline
\end{tabular}

Table 3. Growth of five isolates of $F$. oxysporum f. sp. ricini on different media after eight days of incubation at $27 \pm 2^{\circ} \mathrm{C}$.

\begin{tabular}{llllllll}
\hline \multirow{2}{*}{ Isolates } & \multicolumn{2}{l}{ Colony diameter $(\mathbf{m m})^{*}$} & & & \\
\cline { 2 - 7 } & $\begin{array}{l}\text { Potato dex- } \\
\text { trose agar }\end{array}$ & $\begin{array}{l}\text { Asthana } \\
\text { Hawker's agar }\end{array}$ & $\begin{array}{l}\text { and } \\
\text { agar }\end{array}$ & Bengal & $\begin{array}{l}\text { Glucose aspar- } \\
\text { agine agar }\end{array}$ & $\begin{array}{l}\text { Richard's } \\
\text { agar }\end{array}$ & Mean \\
\hline For-1 & 72.50 & 70.83 & 15.50 & 65.33 & 71.83 & 59.20 \\
For-2 & 58.16 & 40.66 & 17.16 & 40.66 & 49.66 & 41.26 \\
For-3 & 78.16 & 66.83 & 20.00 & 64.66 & 75.83 & 61.10 \\
For-4 & 82.33 & 65.83 & 22.66 & 61.00 & 68.33 & 60.03 \\
For-5 & 61.83 & 58.33 & 19.66 & 55.00 & 68.16 & 52.60 \\
Mean & 70.60 & 60.50 & 19.00 & 57.33 & 66.76 & - \\
C. D. at 5 & Isolates (A) & $: 1.39$ & & & \\
\% & Media (B) & $: 1.39$ & & & \\
\hline
\end{tabular}

${ }^{*}$ Mean of three replications.

mum mean growth was observed with For 3 $(61.10 \mathrm{~mm})$ and For $4(60.03 \mathrm{~mm})$ which were statistically similar and fallowed by For 1 (59.20 $\mathrm{mm})$, For $5(52.60 \mathrm{~mm})$ and For $2(41.26 \mathrm{~mm})$. Interaction of different isolates and media was significant in the respect of growth rate and isolates For 4 exhibited maximum growth $(82.33 \mathrm{~mm})$ on PDA which was followed by isolate For 3 on PDA $(78.16 \mathrm{~mm})$ and RA $(75.83 \mathrm{~mm})$. All the isolates poorly grew in RBA. There was a considerable variation among all the five isolates of $F$. oxysporum f. sp. ricini. The cultural variability among different isolates of castor wilt pathogen, $F$. oxysporum f. sp. ricini collected from different castor growing areas of the country were also observed by Piplani et al.(1985), Desai et al. (2003), Prasad et al. (2008) and Mulekar et al. (2017).

In the liquid media study, growth of dry mycelium, sporulation and morphological observation of all the five isolates grown in different media. There was also variation in dry mycelial weight among different media as well as isolates (Table 4).

Among different five media, significantly maximum mean dry mycelial weight $(290.73 \mathrm{mg})$ was record- 
Table 4. Dry mycelial weight of five isolates of $F$. oxysporum f. sp. ricini grown in different liquid media after fifteen days of incubation at $27 \pm 2^{\circ} \mathrm{C}$.

\begin{tabular}{|c|c|c|c|c|c|c|}
\hline \multirow[b]{2}{*}{ Isolates } & \multicolumn{5}{|c|}{ Dry mycelial weight (mg) } & \multirow[b]{2}{*}{ Mean } \\
\hline & $\begin{array}{l}\text { Potato dex- } \\
\text { trose agar }\end{array}$ & $\begin{array}{l}\text { Asthana and } \\
\text { Hawker's agar }\end{array}$ & $\begin{array}{l}\text { Rose Bengal } \\
\text { agar }\end{array}$ & $\begin{array}{l}\text { Glucose aspara- } \\
\text { gine agar }\end{array}$ & $\begin{array}{l}\text { Richard's } \\
\text { agar }\end{array}$ & \\
\hline For-1 & 128.00 & 46.66 & 39.33 & 59.66 & 323.00 & 119.33 \\
\hline For-2 & 119.33 & 39.66 & 41.00 & 25.66 & 301.66 & 105.46 \\
\hline For-3 & 129.33 & 39.66 & 50.66 & 44.00 & 255.00 & 103.73 \\
\hline For-4 & 116.33 & 33.33 & 38.66 & 34.66 & 254.66 & 95.53 \\
\hline For-5 & 149.66 & 38.33 & 38.66 & 44.33 & 319.33 & 118.06 \\
\hline Mean & 128.53 & 39.53 & 41.66 & 41.66 & 290.73 & - \\
\hline \multirow{3}{*}{$\begin{array}{l}\text { C. D. at } 5 \\
\%\end{array}$} & & Isolates (A) & $: 6.99$ & & & \\
\hline & & Media (B) & $: 6.99$ & & & \\
\hline & & $A \times B$ & : 15.64 & & & \\
\hline
\end{tabular}

${ }^{*}$ Mean of three replications.

Table 5. Sporulation of five isolates of $F$. oxysporum f. sp. ricini grown in different liquid media after 15 days of incubation at $27 \pm 2{ }^{\circ} \mathrm{C}$.

\begin{tabular}{lllllll}
\hline $\begin{array}{l}\text { Iso- } \\
\text { lates }\end{array}$ & \begin{tabular}{l} 
Sporulation (millions/ml) \\
\cline { 2 - 7 } \\
Potato dex- \\
trose agar
\end{tabular} & $\begin{array}{l}\text { Asthana } \\
\text { Hawker's agar }\end{array}$ & $\begin{array}{l}\text { Rose Bengal } \\
\text { agar }\end{array}$ & $\begin{array}{l}\text { Glucose aspara- } \\
\text { gine agar }\end{array}$ & $\begin{array}{l}\text { Richard's } \\
\text { agar }\end{array}$ & Mean \\
\hline For-1 & 23.03 & 9.90 & 3.16 & 12.50 & 15.43 & 12.80 \\
For-2 & 6.70 & 3.70 & 2.23 & 0.83 & 3.36 & 3.36 \\
For-3 & 17.83 & 2.33 & 0.96 & 12.43 & 7.60 & 8.23 \\
For-4 & 33.53 & 5.73 & 2.36 & 22.16 & 15.96 & 15.95 \\
For-5 & 12.63 & 5.20 & 1.23 & 4.33 & 6.50 & 5.98 \\
Mean & 18.74 & 5.37 & 1.99 & 10.45 & 9.77 \\
C. D. at 5 & Isolates (A) & $: 1.17$ & & & \\
$\%$ & Media (B) & $: 1.17$ & & & \\
\hline
\end{tabular}

${ }^{*}$ Mean of three replications.

ed in Richard's medium followed by PD medium (128.53 mg). Maximum mean dry mycelial weight was exhibited by For 1 (119.33 mg) and For 5 (118.06 mg) which were statistically equal. This was followed by isolates For 2 and For 3 which produced mean dry mycelial weight by 105.46 and $103.73 \mathrm{mg}$, respectively. Statistically significant interaction of different isolates and media in the respect of dry mycelial weight was observed. Maximum dry mycelia weight was recorded on Richard's medium for all five isolates followed by PD medium. Significantly higher mean sporulation (18.74 million $/ \mathrm{ml}$ ) was in PD medium (Table 5) followed by GA medium (10.45 million $/ \mathrm{ml}$ ) and Richard's medium (9.77 million/ml).

Maximum mean sporulation (15.95 million $/ \mathrm{ml}$ ) was recorded with For 4 followed by For 1 (12.80 million $/ \mathrm{ml}$ ) and For 3 (8.23 million/ml). Interaction of different isolates and media was significant in the respect of sporulation. The isolates For 4 preferred PD, GA and Richard's media for sporulation (33.53 million/ml, $22.16 \mathrm{million} / \mathrm{ml}$ and $15.43 \mathrm{mil}-$ lion $/ \mathrm{ml}$, respectively) and For 1 preferred $\mathrm{AH}$ (19.90 million $/ \mathrm{ml}$ ) and RB medium (3.16 million/ $\mathrm{ml}$, respectively) over other media. The present findings are in agreement with work of Mishra and Dhar (2007) they studied four liquid media for mycelial growth and sporulation of $F$. udum isolates and observed wide variation among the isolates in respect of mycelia growth and sporulation according to different media. Kumar and Upadhyay (2014) collected fifteen isolates of $F$. udum from Bihar, Jharkhand, Orrisa and West Bengal states and observed variability and dry mycelium weight was ranged from 98.3 to 201.0 milligram, while number of spores ranged from 0.8 to 3.6 million per millilitre with Potato dextrose broth. The result obtained by above research workers supported the finding of present research work.

Morphological study revealed the variation in size of microconidia and macroconidia among five isolates of castor wilt pathogen grown in different liquid media. The microconidia were $0-1$ septate, whereas the macroconidia were $2-15$ septate (Table 6 ).

In PD medium, the average length of microconidia varied from $8.96 \mu \mathrm{m}(4.80-16.00 \mu \mathrm{m})$ of isolates For 3 to $11.12 \mu \mathrm{m}(6.40-14.40 \mu \mathrm{m})$ of isolates For 1 , while the breadth of microconidia from $3.29 \mu \mathrm{m}$ (2.24-4.80 $\mu \mathrm{m})$ of isolates For 5 to $4.72 \mu \mathrm{m}$ (3.20$9.60 \mu \mathrm{m})$ of isolates For 4. The average length of macroconidia varied from $18.56 \mu \mathrm{m}(11.20-32.00$ $\mu \mathrm{m})$ of isolates For 4 to $25.04 \mu \mathrm{m}(16.00-35.20$ $\mu \mathrm{m}$ ) of isolates For 1 , while the breadth of macroconidia from $3.28 \mu \mathrm{m}(3.20-4.80 \mu \mathrm{m})$ of isolates For 5 to $3.92 \mu \mathrm{m}(3.20-6.40 \mu \mathrm{m})$ of isolates For 3 . In $\mathrm{AH}$ medium, the length of microconidia varied from $6.16 \mu \mathrm{m}(4.80-10.24 \mu \mathrm{m})$ of isolates For 3 to $10.19 \mu \mathrm{m}(6.40-13.12 \mu \mathrm{m})$ of isolates For 1 , while 
Sangava, M. et al. / J. Appl. \& Nat. Sci. 10 (4): 1291-1296 (2018)

Table 6. Size of microconidia and macroconidia of five isolates of $F$. oxysporum f. sp. ricini grown in different liquid media after 15 days of incubation at $27 \pm 2^{\circ} \mathrm{C}$.

\begin{tabular}{|c|c|c|c|c|c|c|c|c|c|c|c|}
\hline \multirow{3}{*}{ Media } & \multirow{3}{*}{$\begin{array}{l}\text { Iso- } \\
\text { lates }\end{array}$} & \multirow{2}{*}{\multicolumn{2}{|c|}{$\begin{array}{l}\text { Microconidia } \\
\text { Length }(\mu \mathrm{m})\end{array}$}} & \multirow{2}{*}{\multicolumn{2}{|c|}{ Breadth $(\mu \mathrm{m})$}} & \multirow{3}{*}{$\begin{array}{l}\text { Septa- } \\
\text { tion }\end{array}$} & \multirow{2}{*}{\multicolumn{2}{|c|}{$\begin{array}{l}\text { Macroconidia } \\
\text { Length }(\mu \mathrm{m}) \\
\end{array}$}} & \multirow{2}{*}{\multicolumn{2}{|c|}{ Breadth $(\mu \mathrm{m})$}} & \multirow{3}{*}{$\begin{array}{l}\text { Sep- } \\
\text { tation }\end{array}$} \\
\hline & & & & & & & & & & & \\
\hline & & Range & $\begin{array}{l}\text { Aver- } \\
\text { age }\end{array}$ & Range & $\begin{array}{l}\text { Aver- } \\
\text { age }\end{array}$ & & Range & $\begin{array}{l}\text { Aver- } \\
\text { age }\end{array}$ & Range & $\begin{array}{l}\text { Aver- } \\
\text { age }\end{array}$ & \\
\hline \multirow{5}{*}{$\begin{array}{l}\text { Potato dex- } \\
\text { trose (PD) } \\
\text { medium }\end{array}$} & For-1 & $\begin{array}{l}6.40- \\
14.40\end{array}$ & 11.12 & $\begin{array}{l}2.88- \\
5.76\end{array}$ & 3.69 & $0-1$ & $\begin{array}{l}16.00- \\
35.20\end{array}$ & 25.04 & $\begin{array}{l}3.20- \\
6.40\end{array}$ & 3.60 & $3-7$ \\
\hline & For-2 & $\begin{array}{l}4.80- \\
12.80\end{array}$ & 9.68 & $\begin{array}{l}3.20- \\
4.80\end{array}$ & 3.42 & $0-1$ & $\begin{array}{l}12.80- \\
25.60\end{array}$ & 20.96 & $\begin{array}{l}3.20- \\
4.80\end{array}$ & 3.52 & $3-5$ \\
\hline & For-3 & $\begin{array}{l}4.80- \\
16.00\end{array}$ & 8.96 & $\begin{array}{l}3.20- \\
6.40\end{array}$ & 3.84 & $0-1$ & $\begin{array}{l}12.80- \\
44.80\end{array}$ & 22.40 & $\begin{array}{l}3.20- \\
6.40\end{array}$ & 3.92 & $3-5$ \\
\hline & For-4 & $\begin{array}{l}6.40- \\
16.00\end{array}$ & 9.92 & $\begin{array}{l}3.20- \\
9.60\end{array}$ & 4.72 & $0-1$ & $\begin{array}{l}11.20- \\
32.00\end{array}$ & 18.56 & $\begin{array}{l}2.56- \\
4.80\end{array}$ & 3.39 & $3-6$ \\
\hline & For-5 & $\begin{array}{l}4.80- \\
16.00\end{array}$ & 9.04 & $\begin{array}{l}2.24- \\
4.80\end{array}$ & 3.29 & $0-1$ & $\begin{array}{l}16.00- \\
35.20\end{array}$ & 24.08 & $\begin{array}{l}3.20- \\
4.80\end{array}$ & 3.28 & $3-7$ \\
\hline \multirow{5}{*}{$\begin{array}{l}\text { Asthana } \\
\text { and Hawk- } \\
\text { er's (AH) } \\
\text { medium }\end{array}$} & For-1 & $\begin{array}{l}6.40- \\
13.12\end{array}$ & 10.19 & $\begin{array}{l}3.20- \\
8.00\end{array}$ & 5.49 & $0-1$ & $\begin{array}{l}19.20- \\
70.40\end{array}$ & 39.44 & $\begin{array}{l}3.20- \\
5.44\end{array}$ & 4.06 & $4-15$ \\
\hline & For-2 & $\begin{array}{l}3.20- \\
10.89\end{array}$ & 6.24 & $\begin{array}{l}2.88- \\
5.44\end{array}$ & 3.39 & $0-1$ & $\begin{array}{l}8.00- \\
16.00\end{array}$ & 11.90 & $\begin{array}{l}3.20- \\
5.44\end{array}$ & 4.16 & $3-4$ \\
\hline & For-3 & $\begin{array}{l}4.80- \\
10.24\end{array}$ & 6.16 & $\begin{array}{l}2.88- \\
4.80\end{array}$ & 3.20 & $0-1$ & $\begin{array}{l}8.00- \\
25.60\end{array}$ & 11.01 & $\begin{array}{l}3.20- \\
5.44\end{array}$ & 3.76 & $3-6$ \\
\hline & For-4 & $\begin{array}{l}6.40- \\
13.12\end{array}$ & 9.30 & $\begin{array}{l}3.20- \\
5.76\end{array}$ & 4.20 & $0-1$ & $\begin{array}{l}12.8- \\
48.32\end{array}$ & 26.92 & $\begin{array}{l}3.20- \\
5.76\end{array}$ & 4.02 & $3-9$ \\
\hline & For-5 & $\begin{array}{l}3.20- \\
12.80\end{array}$ & 7.52 & $\begin{array}{l}2.24- \\
6.40\end{array}$ & 3.66 & $0-1$ & $\begin{array}{l}22.40- \\
46.40\end{array}$ & 31.65 & $\begin{array}{l}3.20- \\
6.40\end{array}$ & 4.16 & $4-7$ \\
\hline \multirow{5}{*}{$\begin{array}{l}\text { Rose Ben- } \\
\text { gal (RB) } \\
\text { medium }\end{array}$} & For-1 & $\begin{array}{l}4.80- \\
12.80\end{array}$ & 8.50 & $\begin{array}{l}2.24- \\
5.44\end{array}$ & 3.82 & $0-1$ & $\begin{array}{l}11.20- \\
32.32\end{array}$ & 18.96 & $\begin{array}{l}3.52- \\
6.72\end{array}$ & 4.11 & $3-5$ \\
\hline & For-2 & $\begin{array}{l}5.44- \\
12.80\end{array}$ & 8.11 & $\begin{array}{l}2.88- \\
5.12\end{array}$ & 3.92 & $0-1$ & $\begin{array}{l}13.12- \\
24.00\end{array}$ & 17.21 & $\begin{array}{l}3.20- \\
5.76\end{array}$ & 3.90 & $3-5$ \\
\hline & For-3 & $\begin{array}{l}6.40- \\
9.92\end{array}$ & 8.22 & $\begin{array}{l}3.20- \\
5.44\end{array}$ & 4.14 & $0-1$ & $\begin{array}{l}12.80- \\
20.48\end{array}$ & 15.84 & $\begin{array}{l}3.20- \\
4.16\end{array}$ & 3.65 & $3-4$ \\
\hline & For-4 & $\begin{array}{l}6.40- \\
11.20\end{array}$ & 7.33 & $\begin{array}{l}2.56- \\
4.80\end{array}$ & 3.52 & $0-1$ & $\begin{array}{l}12.80- \\
25.92\end{array}$ & 17.63 & $\begin{array}{l}2.88- \\
4.80\end{array}$ & 3.66 & $3-4$ \\
\hline & For-5 & $\begin{array}{l}6.72- \\
11.20\end{array}$ & 9.57 & $\begin{array}{l}2.88- \\
6.40\end{array}$ & 4.18 & $0-1$ & $\begin{array}{l}12.80- \\
22.72\end{array}$ & 17.60 & $\begin{array}{l}2.56- \\
4.48\end{array}$ & 3.25 & $3-4$ \\
\hline \multirow{5}{*}{$\begin{array}{l}\text { Glucose } \\
\text { asparagine } \\
\text { (GA) medi- } \\
\text { um }\end{array}$} & For-1 & $\begin{array}{l}6.08- \\
9.92\end{array}$ & 8.25 & $\begin{array}{l}2.88- \\
4.80\end{array}$ & 3.87 & $0-1$ & $\begin{array}{l}13.12- \\
32.00\end{array}$ & 21.86 & $\begin{array}{l}3.52- \\
4.80\end{array}$ & 4.13 & $3-5$ \\
\hline & For-2 & $\begin{array}{l}7.68- \\
9.60\end{array}$ & 8.61 & $\begin{array}{l}2.56- \\
4.16\end{array}$ & 3.46 & $0-1$ & $\begin{array}{l}13.44- \\
32.32\end{array}$ & 18.37 & $\begin{array}{l}3.52- \\
4.48\end{array}$ & 3.94 & $3-5$ \\
\hline & For-3 & $\begin{array}{l}6.40- \\
10.24\end{array}$ & 8.57 & $\begin{array}{l}3.20- \\
4.80\end{array}$ & 3.94 & $0-1$ & $\begin{array}{l}19.20- \\
38.72\end{array}$ & 25.47 & $\begin{array}{l}3.50- \\
4.48\end{array}$ & 4.13 & $3-7$ \\
\hline & For-4 & $\begin{array}{l}4.80- \\
12.80\end{array}$ & 8.83 & $\begin{array}{l}3.20- \\
5.44\end{array}$ & 4.32 & $0-1$ & $\begin{array}{l}12.80- \\
26.56\end{array}$ & 20.74 & $\begin{array}{l}3.20- \\
640\end{array}$ & 4.42 & $3-9$ \\
\hline & For-5 & $\begin{array}{l}3.52- \\
12.80\end{array}$ & 7.71 & $\begin{array}{l}1.92- \\
4.48\end{array}$ & 3.55 & $0-1$ & $\begin{array}{l}9.92- \\
46.40\end{array}$ & 29.18 & $\begin{array}{l}3.52- \\
6.08\end{array}$ & 4.22 & $3-11$ \\
\hline \multirow{5}{*}{$\begin{array}{l}\text { Richard's } \\
\text { medium }\end{array}$} & For-1 & $\begin{array}{l}4.80- \\
14.08\end{array}$ & 9.85 & $\begin{array}{l}3.20- \\
5.44\end{array}$ & 4.38 & $0-1$ & $\begin{array}{l}7.68- \\
25.28\end{array}$ & 13.50 & $\begin{array}{l}3.20- \\
5.44\end{array}$ & 4.19 & $3-5$ \\
\hline & For-2 & $\begin{array}{l}5.76- \\
10.88\end{array}$ & 7.52 & $\begin{array}{l}3.20- \\
5.12\end{array}$ & 4.26 & $0-1$ & $\begin{array}{l}8.64- \\
13.44\end{array}$ & 10.94 & $\begin{array}{l}3.52- \\
4.48\end{array}$ & 3.84 & $2-4$ \\
\hline & For-3 & $\begin{array}{l}5.44- \\
14.40\end{array}$ & 8.96 & $\begin{array}{l}3.20- \\
4.80\end{array}$ & 4.12 & $0-1$ & $\begin{array}{l}11.20- \\
20.16\end{array}$ & 14.02 & $\begin{array}{l}3.52- \\
5.12\end{array}$ & 4.00 & $2-4$ \\
\hline & For-4 & $\begin{array}{l}6.72- \\
19.52\end{array}$ & 12.25 & $\begin{array}{l}3.84- \\
6.40\end{array}$ & 4.77 & $0-1$ & $\begin{array}{l}9.92- \\
21.44\end{array}$ & 14.27 & $\begin{array}{l}3.52- \\
5.44\end{array}$ & 4.48 & $3-6$ \\
\hline & For-5 & $\begin{array}{l}6.40- \\
19.20 \\
\end{array}$ & 11.48 & $\begin{array}{l}3.52- \\
5.12\end{array}$ & 4.38 & $0-1$ & $\begin{array}{l}9.92- \\
25.97\end{array}$ & 16.10 & $\begin{array}{l}3.20- \\
4.48\end{array}$ & 3.81 & $3-7$ \\
\hline
\end{tabular}

the breadth of microconidia from $3.20 \mu \mathrm{m}(2.88-$ $4.80 \mu \mathrm{m})$ of isolates For 3 to $5.49 \mu \mathrm{m}(3.20-8.00$ $\mu \mathrm{m})$ of isolates For 1 . The average length of macroconidia varied from $11.01 \mu \mathrm{m}(8.00-25.60 \mu \mathrm{m})$ of isolates For 3 to $39.44 \mu \mathrm{m}(19.20-70.40 \mu \mathrm{m})$ of isolates For 1 , while the breadth of macroconidia from $3.76 \mu \mathrm{m}(3.20-5.44 \mu \mathrm{m})$ of isolates For 3 to $4.16 \mu \mathrm{m}(3.20-6.40 \mu \mathrm{m})$ of isolates For 5. The isolates For 1 produced 4-15 septate straight as well as sickle shaped macroconidia on Asthana and Hawker's medium. In RB medium, the length of microconidia varied from $7.33 \mu \mathrm{m} \quad(6.40-11.20$ $\mu \mathrm{m})$ of isolates For 4 to $9.57 \mu \mathrm{m}(6.72-11.20 \mu \mathrm{m})$ of isolates For 5 , while the breadth of microconidia from $3.52 \mu \mathrm{m}(2.56-4.80 \mu \mathrm{m})$ of isolates For 4 to $4.18 \mu \mathrm{m}(2.88-6.40 \mu \mathrm{m})$ of isolates For 5. The length of macroconidia varied from $15.84 \mu \mathrm{m}$ $(12.80-20.48 \mu \mathrm{m})$ of isolates For 3 to $18.96 \mu \mathrm{m}$ (11.20-32.32 $\mu \mathrm{m})$ of isolates For 1 , while the breadth of macroconidia from $3.25 \mu \mathrm{m}(2.56-4.48$ $\mu \mathrm{m})$ of isolates For 5 to $4.11 \mu \mathrm{m}$ (3.52-6.72 $\mu \mathrm{m})$ of isolates For 1. In GA medium, the length of microconidia varied from $7.71 \mu \mathrm{m}(3.52-12.80 \mu \mathrm{m})$ of isolates For 5 to $8.83 \mu \mathrm{m}(4.80-12.80 \mu \mathrm{m})$ of iso- 
lates For 4 , while the breadth of microconidia from $3.46 \mu \mathrm{m}(2.56-4.16 \mu \mathrm{m})$ of isolates For 2 to $4.32 \mu \mathrm{m}(3.20-5.44 \mu \mathrm{m})$ of isolates For 4. The length of macroconidia varied from $18.37 \mu \mathrm{m}$ (13.44-32.32 $\mu \mathrm{m})$ of isolates For 2 to $29.18 \mu \mathrm{m}$ $(9.92-46.40 \mu \mathrm{m})$ of isolates For 5, while the breadth of macroconidia from $3.94 \mu \mathrm{m}$ (3.52-4.48 $\mu \mathrm{m})$ of isolates For 2 to $4.42 \mu \mathrm{m}(3.20-6.40 \mu \mathrm{m})$ of isolates For 4. In Richard's medium, the length of microconidia varied from $7.52 \mu \mathrm{m}(5.76-10.80 \mu \mathrm{m})$ of isolates For 2 to $12.25 \mu \mathrm{m}(6.72-19.52 \mu \mathrm{m})$ of isolates For 4 , while the breadth of microconidia from $4.12 \mu \mathrm{m}(3.20-4.80 \mu \mathrm{m})$ of isolate s For 3 to $4.77 \mu \mathrm{m}(3.84-6.40 \mu \mathrm{m})$ of isolates For 4. The length of macroconidia varied from $10.94 \mu \mathrm{m}$ (8.64-13.44 $\mu \mathrm{m})$ of isolates For 2 to $16.10 \mu \mathrm{m}$ $(9.92-25.92 \mu \mathrm{m})$ of isolates For 5 , while the breadth of macroconidia from $3.81 \mu \mathrm{m}(3.20-4.48$ $\mu \mathrm{m})$ of isolates For 5 to $4.48 \mu \mathrm{m}$ (3.52-5.44 $\mu \mathrm{m})$ of isolates For 4. The present findings are in agreement with work done on different formae species of Fusarium wilt by several workers. Previously, Piplani et al. (1985), Desai et al. (2003), Chauhan (2007) and Prasad et al. (2008) reported morphological variability among different isolates of $F$. oxysporum f. sp. ricini. Presence of genetic variation in different isolates of $F$. oxysporum f.sp. ricini isolated from different castor growing regions has been reported by Prasad et al. (2008). Diverse cultural, morphological and pathogenic characteristics were recorded in different $F$. oxysporum f.sp. ricini isolates and it was also observed that highly virulent isolates produces abundant spores as compared to moderately virulent isolates (Nanda and Parasad, 1974; Desai et al., 2003). Mulekar et al. (2017) recorded morphological variability in 24 isolates of Fusarium oxysporum f.sp. ricini representing various castor growing regions of India in Andhra Pradesh, Gujarat, Rajasthan Tamil Nadu, Telangana states. Similarly in the present study, significant variation in growth and sporulation of five isolates of Fusarium oxysporum f.sp. ricini representing various castor growing areas of Gujarat was observed. The results indicate existence of variability in the respect of morphological character among five isolates of $F$. oxysporum f.sp. ricini causing wilt disease in castor. Each isolate exhibited cultural and morphological variation influence by different media and this may be due to varied compositions of growth media which provides different kinds of nutrition.

\section{Conclusion}

This was concluded that there was a significant variation among all five isolates of $F$. oxysporum f.sp. ricini collected from different castor growing areas of Gujarat. The findings will be useful for developing Fusarium wilt resistant castor hybrids/ varieties.

\section{REFERENCES}

1. Anonymous (2018). Annual report, Castor, 2017-18, ICAR-Indian Institute of Oilseeds Research, Rajendranagar, Hyderabad, India. p.130-131.

2. Chauhan, D.K. (2007). Studies on variability of wilt pathogen (Fusarium oxysporum f. sp. ricini Nanda and Prasad) of castor. M.Sc. (Agri.) Thesis submitted to Sardarkrushinagar Dantiwada Agricultural University, Sardarkrushinagar (Gujarat) India.

3. Dange, S.R.S., Desai, A.G. and Patel, D.B. (1997). Management of wilt of castor in Gujarat State in India. In: Proceedings of International Conference on Integrated Plant Disease Management for Sustainable Agriculture. 10-15 Nov. IARI, New Delhi, India. pp. 107

4. Dange, S.R.S. (2003). Wilt of castor - An overview. Journal of Mycology and Plant Pathology.33:333-339

5. Desai, A.G., Dange, S.R.S., Patel, D.S. and Patel, D.B. (2003). Variability in Fusarium oxysporum f. sp. ricini, causing wilt of castor. Journal of Mycology and Plant Pathology. 33: 37-41.

6. Kumar, S. and Upadhyay, J.P. (2014). Studies on cultural, morphological and pathogenic variability in isolates of Fusarium udum causing wilt of pigeonpea. Indian Phytopathology. 67(1): 55-58.

7. Lakshminarayana, M. and Raoof, M.A. (2006). Research Achievements. C. Crop Protection. In : AICRP on Castor, DOR, 2006. Research Achievements in Castor. Hegde, D.M. (Ed.). All India Co-ordinated Research Project on Castor, Directorate of Oilseeds Research, India. p.49-80.

8. Mishra, S. and Dhar, V. (2007). Influence of nutritional media, $\mathrm{pH}$ and temperature on mycelial growth and sporulation of Fusarium udum. Journal of Food Legumes. 20: 192-195.

9. Moshkin, V.A. (1986). Castor. Amerind Publishing Co. Pvt. Ltd., New Delhi. pp.315.

10.Niks, R.E., Ellis, P.R. and Parlevliet, J.E. (1993). Resistance to parasites. In: Plant breeding: principles and prospects. Hayward, M.D., Bosemark, N.O. and Romagosa, I. (eds). Chapman and Hall, London. p.422-447.

11.Piplani, S., Gemawat, P.D. and Prasad, N. (1985). Morphology and taxonomy of castor Fusarium. Journal Mycology and Plant Pathology. 16: 42-47.

12.Prasad, M.S.L., Sujatha, M. and Raoof, M.A. (2008). Morphological, pathogenic and genetic variability in castor wilt isolates.Indian Phytopathology.61(1):18-27

13.Raoof, M.A. and NageshwarRao, T.G. (1999). Castor diseases and their integrated management. In: IPM Systems in Agriculture. Upadhyay, R., Mukherji, K.G. and Rajak, R.L. (Eds.) Vol. 5 (Oilseeds). Aditiya Books Pvt. Ltd., New Delhi. p.559-574.

14.Sinclair, J.B. and Dhingra, O.D. (1995). Basic Plant Pathology Methods, $2^{\text {nd }}$ Edition. CRC Press. p. 448.

15.Mulekar, V.G., Desai, A.G. and Chavan, A.A. (2017). Studies on morphological variability in Fusarium oxysporum f. sp. ricini causing wilt of castor. Trends in Biosciences. 10(4): 1232-1236.

16.Nanda, S. and Prasad, N. (1974). Wilt of castor- a new record. Indian Journal of Mycology and Plant Pathology. 4: 103-105

17.Patel, D.R., Patel, D.S. and Patel, I.D. (1991). A high yielding $\mathrm{GCH}-4$ castor hybrid is resistant to wilt. Indian Farming (June), p.11-12.

18.Anjani, K., Jain, S.K., Tayagi, B.S., Saxena, R.K. and Agrawal, A. (2004). Plant genetic resources: Oilseed and cash crops. Narosa Publishing House, New Delhi, India. p.105-117. 